\title{
Student perceptions of distance learning at advanced level in Zimbabwe
}

Gomba, Clifford $\bigotimes$

Dreeben School of Education, University of the Incarnate Word, Texas, USA (cgomba@uiwtx.edu)

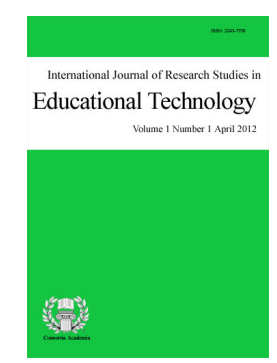

\section{Abstract}

Thirty-four Zimbabwean Advanced level students at a Catholic run boarding school were surveyed in regards to their perception of having distance education at high school level. The country is experiencing an increase in technology use, resulting in calls for the introduction of online education through distance learning (Bukaliya \& Musika, 2011). The purpose of this survey study is to investigate the attitudes and perceptions of high school students in Zimbabwe towards distance learning. Participants completed a 15-item tool with domains in computer, internet, online learning, teachers and overall expectations of online education. The results showed that most of the participants favored the introduction of blended learning at Advanced level as opposed to having online learning. It is the author's recommendation that steps should be made towards training instructors in online teaching, and helping schools introduce blended education into their curriculum. Professional development of teachers should also focus on the training of using computers in the classroom.

Keywords: distance learning; blended learning; advanced level; online education; Zimbabwe Open University 


\section{Student perceptions of distance learning at advanced level in Zimbabwe}

\section{Introduction}

With the advance of technology, distance learning has become a popular and practical choice with the potential to function as an important education delivery system (Roblyer, 1999). Distance education in Zimbabwe was born out of necessity and also to correct the imbalances in education created by the colonial government (Kurasha, 2003). After Zimbabwe gained independence in 1980, the Williams Commission of 1981 recommended the establishment up of a Center for Distance Education (CDE) to train teachers. CDE was transformed into a fully-fledged distance university in 1999, and was named Zimbabwe Open University (ZOU). Initially, distance education in Zimbabwe was limited to adults only as they were the ones who were considered to have been left behind in education due to colonial imbalances. The primary formats used in distance education were radio and post. ZOU is recognized as a credible university offering distance education to the disadvantaged members of the society including those who are disabled (Chimhenga \& Musarurwa, 2012).

The current distance education situation in Zimbabwe indicates a need to broaden the scope of distance learning. If this concept could be deployed to other groups, such as high school students, it may be possible to realize the benefits of distance learning for more students. Distance learning has come of age in Zimbabwe as it now has gone online to reach a wider audience (Bukaliya \& Musika, 2011). ZOU caters mainly to degree-seeking students (Kurasha, 2003; Nyaruwata, 2011), however, although ZOU also offers open and distance learning programs among secondary school students, most people are unaware (Bukaliya \& Musika, 2011). Thirty-four Zimbabwean Advanced level students at a Catholic run boarding school were surveyed in regards to their perception of having distance education at high school level. The country is experiencing an increase in technology use, resulting in calls for the introduction of online education through distance learning (Bukaliya \& Musika, 2011). The purpose of this survey study is to investigate the attitudes and perceptions of high school students in Zimbabwe towards distance learning. Participants completed a 15-item tool with domains in computer, internet, online learning, teachers and overall expectations of online education. The results showed that most of the participants favored the introduction of blended learning at Advanced level as opposed to having online learning. It is the author's recommendation that steps should be made towards training instructors in online teaching, and helping schools introduce blended education into their curriculum. Professional development of teachers should also focus on the training of using computers in the classroom.

\subsection{Distance Learning in Education}

Yang (2008) has identified the distance learning serving as an imperative vehicle in the context of lifelong learning, which provides "a way of widening access to flexible educational opportunities" (p. 586). Milcheva (2012) noted that "the development of distance learning is a result of the development of societal needs for education, training, information and communication technologies" (p. 345). Further, he pointed out the main issue of implementation of distance learning is rooted in the form of learning that how the learning process and individual learners will be structured. According to Loveland, Miyakawa, and Yoshitaka's (2004) literature review, they have identified several technologies used in distance learning: Internet (research, e-mailing), desktop teleconferencing (NetMeeting, CUCMe), video teleconference (Oicture-Tel, ISDN lines), and interactive multimedia (PowerPoint, Web page design). Roblyer (1999) argues that it might be rational and of significance for K-12 institutions to offer online alternative to traditional campus programs, but stated that it is however less urgent.

Online learning is one of the fastest growing trends in educational technology (CDLP, 2011; Siegle, 2010). It is an education trend that is being used to reach to students who otherwise cannot attend traditional classroom. Students who may be unable to attend classes due to physical illness, expulsion, or location may have a chance 
to continue with their education. Using online learning, students can learn anytime, and anywhere, making it also suitable for students with work and family commitments (Coleman, 2012). Online learning is now making it possible for those in need of an education to acquire it, even while working (Abarashi, 2011).

Online learning has become popular because it provides more flexible access to content and instruction at any time from any place (Kurasha, 2003; Siegle, 2010; US Department of Education, 2010; Zindi, 1997). Course material is available 24/7 (Barbour \& Reeves, 2009), thus it is accessible anytime such that students have the ability to review the lesson whenever they want (Coleman, 2012). Online learning provides room for individual instruction to meet specific needs and learning styles of students (Barbour \& Reeves, 2009). In the online learning environment, participation is critical to demonstrate student engagement. Effectively administered, all students are provided the opportunity to participate, increasing student interaction (Coleman, 2012).

Online learning also affords the opportunity for anonymous participation reducing or eliminating bias associated with gender, age and race. In online learning, students are treated equally and have more opportunity and time to think thoroughly before they respond (Coleman, 2012). In an online environment, students do not need to commute to school, thus saving money and time (Abarashi, 2011). Students can communicate with their instructors freely and openly without having to wait for office hours, and without feeling ashamed by being observed by others (Coleman, 2012).

Online learning can take the form of hybrid/blended learning where there is integration of face-to-face and online components (iNACOL, 2011; Picciano, Seaman, \& Day, 2011). In addition online learning may be in synchronous (learning in real time) and or asynchronous (learning in different times and places) modes (Hranstinski, 2008; iNACOL, 2011). Online learning is improving as new tools and technology are developed and improved. In addition to being flexible, online learning is also affordable, effective, interactive, and efficient (Florida Center for Instructional Technology, 2009).

Antunes (2008) developed a pedagogy model that blended distance learning and collaborative work with online activities in high school context, including several courses; quiz activities, web teaching communities, synchronous training, and web-based courseware. After evaluating these courses, he found that this model described a positive correlation between student learning success and the utilization of online collaborative activities. Antunes (2008) then concluded that "it is possible to teach and simultaneously motivate students to be autonomous" (p. 751). The use of technology as a learning tool motivates students. Roblyer (1999) found the most important reason students choose distance learning was the need and desire for control over their learning environments. Therefore, he suggested that it is better to provide an alternative choice of knowledge delivery systems, such as distance learning. He also suggested that by providing the format of distance learning, it is possible to reduce dropout rates for being responsive to student needs.

Another quasi-experimental study conducted by Lemley, Sudweeks, Howell, Laws, and Sawyer (2007) demonstrated the utility of distance learning. The findings of this study showed that the academic performance of students who enrolled in a Web-based course with immediate feedback was higher than the learning outcomes of students who enrolled in a paper-based course with delayed feedback. Finally, they suggested that in a distance learning setting, providing timely feedback is a best practice.

\subsection{Distance Learning in Education}

Although Zimbabwe is a country which is still grappling with the economic crisis, it has a facility for online learning that is, in most cases, cheaper and may provide a reprieve for those who cannot afford conventional schools. Demand for open learning continues to grow by providing a flexible alternative to tertiary education. Online learning is tailor-made to suit the needs of the society (Kurasha, 2007). Additional flexibility is available as learners have the opportunity to defer exams if they do not have money to pay the exam fees or if they feel they are not ready (Bukaliya \& Musika, 2011). Most schools in Zimbabwe do not have adequate learning materials, and if adopted, online learning provides ample quality resources (Bukaliya \& Musika, 2011). 
The reason distance online learning should be adopted in Zimbabwe is because some learners may fail to complete their studies due to unforeseen circumstances such as pregnancies, especially during high school. Zimbabwean learners who get pregnant have a right to continue with their education (Runhare, 2010). However research has found that some girls who became pregnant prefer to suspend their schooling or transfer to another school after delivery (Runhare, 2010) because pregnant learners are often treated as bad influences on others and are looked down upon. If distance learning were available, learners who become pregnant could enroll for online education or other formats and continue with their education.

For a country that has experienced massive brain drain due to the economic challenges, open and distance learning might actually prove to be a transformative and penetrating tool for harnessing brain drain in Zimbabwe. Zimbabwe and indeed Africa needs to embrace online learning because this new paradigm answers an essential need in Zimbabwe to ensure that good education is truly accessible to all the citizens of the country who desire it (Kurasha, n. d.). Ensuring wider access to education would be an essential part of continuing to build the country as an independent nation. Runhare (2010) found that most schools in Zimbabwe expel students who misbehave or fall pregnant. These expelled students are not be able to continue with their education, as few schools are willing to accept them. In cases like these, online education can enable these students to salvage their educational opportunities. A positive aspect of open and distance education might be brain gain, where the movement of the people will be reduced, and movement of ideas promoted (Kurasha, 2007). With this comes the advantage that learners study at their own pace and in the comfort of their own homes (Tarusikirwa, 2004).

\section{Methodology}

There is no online education (virtual schools) in Zimbabwe that target Ordinary and Advanced level students (Bukaliya \& Musika, 2011). The purpose of this survey study is to investigate the attitudes of high school students in Zimbabwe towards distance learning. By examining their perceptions of distance learning, the education sector might gain insight as they consider introducing the practice of distance learning in high school pedagogy. The study answered the following questions:

1. What are students' perceptions of distance online learning at Advanced level?

2. What are the perceived benefits of distance online learning?

\subsection{Research Design}

This study utilized a cross-sectional survey design (Creswell, 2007). The participants completed the questionnaire at one point in time. The focus of this study is to examine the perceptions of distance learning of high school students in Zimbabwe. Owing to the nature of this study, the researcher outlined the rationale of the questionnaire and exhibited preliminary analyses that illustrate the usefulness of the notion.

\subsection{Participants}

The participants were 34 high school students (16 males, 18 females) with a mean age of 18.35. All participants were aged 18 and above and had the legal standing to consent to complete the survey. The participants attended a rural Catholic high school in the Midlands Province of Zimbabwe. According to their teachers, the students who were enrolled in high school had access to computers at school. Because of time constraints in conducting this research design, convenience sampling was used for this study (Creswell, 2007). The participants were 34 high school students recruited from a high school from a rural area in Zimbabwe.

\subsection{Data Collection}

Data was collected through a survey. The researcher obtained permission to collect data by providing letter of request to the school principal explaining the objectives of the study. The study's objective was to identify 
students' perceptions of the possibility of having an online education at Advanced level. In addition, the study also sought to establish students' perceived benefits of having an online education. All potential participants who were Advanced Level students were assembled in one of their classrooms. One of their teachers introduced me, and I explained the nature and purpose of the survey. I asked for those willing to participate to remain and complete a two-page survey designed for this study.

Of the 52 students in the target population, the sample comprised the 36 chose to remain. The survey required approximately 15 minutes to complete. I was present during the period when participants completed the survey. Of the initial 36 participants, two did not complete the survey and were not included in the data analysis process. The survey consisted of 12 open-ended as well as eight closed-response questions. After the completion of the survey, I collected the completed survey and thanked the students for having participated in the study.

\section{Results}

Of the 34 participants who responded to the survey 29 were boarders, and four were day scholars. The group of participants was made up of 18 females $(52.94 \%)$ and 16 males $(47.06 \%)$. The majority of the participants $(91.2 \%)$ responded that they had heard about online learning and knew what it is. Only $5.9 \%$ of the respondents said they had never had heard of online education. When asked to define online learning briefly, $76.5 \%$ of the participants said it is learning through the use of computer/internet, while $14.7 \%$ said it is distance education. The remainder $5.9 \%$ said it is the interaction of students in the absence of the teacher, while $2.9 \%$ did not respond.

Participants were also asked to state if they had ever used a computer. $82.3 \%$ said they had, while $17.7 \%$ said they had not used a computer before. Of those who claimed to have used a computer before, there was no meaningful statistical difference between males and females. Of the $82.3 \%$ of the participants who said they had used a computer before, 64.7\% indicated that they use the computer for typing, 50\% used it for Facebook and other social activities, $35.3 \%$ for research, $17.7 \%$ use it for email and communication, and $26 \%$ indicated they use the computers for other minor things such as playing games, and downloading music. The participants indicated more than one usage of the computer. The majority of the participants $(86 \%)$ in this study surveyed highlighted that they do have computers at home.

Since Internet was made available at the school in $2011,41.2 \%$ of the participants stated that they had been asked by their teachers to use the computer to research, while $58.8 \%$ said they were never asked to use a computer. Asked to identify the reasons why computers are not used in the classroom, participants' responses varied from teachers' lack of computer skills to shortage of electricity.

Participants were also asked to state their preference on the mode of learning at Advanced level. The majority of students strongly preferred blended learning (51.5\%), while $36.6 \%$ of the participants stated they preferred online learning. The reasons for favoring online and blended learning included the availability of learning material all the time, the opportunity to learn at home, and the opportunity to interact with students from other countries. Participants who stated that they strongly prefer (23.5\%) and prefer (32.4\%) face to face learning said they did not have a continuous access to internet, and that they do not feel comfortable to learn in the absence of teachers and classmates.

\section{Discussions}

The purpose of this study was to understand perceptions and perceived benefits of online learning by students at Advanced level in Zimbabwe. This study's findings presented above are influenced by many factors including the location, individual participants, and subject combinations; hence, they are not generalizable to all Advanced level students in Zimbabwe.

Most of the participants surveyed said that they knew what online education is. The majority of the 
participants were boarders (in most cases the assumption is that they come from well to do parents) and hence may have access to resources including computers. This might explain the reason why most of those surveyed said they had heard about online education, and also had used a computer before. The situation is clearly different for many day scholars who are mostly from the local community (rural area with no electricity) and have difficulty in accessing a computer. The finding from this study is consistent with findings from other research studies that rural based students have a limited access to computers and other technological gadgets (Konyana \& Konyana, 2013) and highlights inequality in accessibility to education.

In terms of using the computer at school, the majority said they had used the computer and there was no difference between males and females in using computers at school. The explanation might be that all the students, whether male or female have some form of equal access to computer use at school. It might be argued that there is no segregation when it comes to computer use at school among the participants. Although there is evidence that shows that women have less access to education in Africa, there is no evidence that shows the disparity in the use of computers (Derbyshire, 2003). Derbyshire (2003) argued that the gender gap in accessing education in Africa is fast closing and that the issue is no longer about access, but about quality education. This quality education is enhanced by the use of computers in both research and presentation of information.

The majority of students indicated that they own a computer at school, and this might have affected the use of computer at school. Computer ownership among students in Africa is lower as compared to the United States but is steadily rising (Calandro, Stork, \& Gillwald, 2012). The study found that participants who owned computers tend to use them at school. Use of a computer at home result in students gaining confidence to use the computer at school (Subrahmanyan, Greenfield, Kraut, \& Gross, 2001). This might explain why students who own computers tend to use them at school.

Participants perceived that a blended education might be used to their advantage instead of having a pure online education. Students preferred blended learning because they did not want to be separated from their teacher for the whole learning period (Mafa, Mpofu, \& Chimhenga, 2013). Constant contact between students and teacher would ensure that the students, at least according to participants view, would be guided physically by the teacher. This view might be supported by the fact that in Zimbabwe, students' resource is mainly the teacher (Ministry of Education, 2004). Studies found those who took blended or hybrid courses had better passes than those who took courses in a traditional classroom (Metz, 2010). Although the study by Metz (2010) was done in a developed world, its conclusions might be replicated to a developing nation like Zimbabwe. Most schools in the country, especially the rural areas do not have enough textbooks. Thus, students tend to depend on the teacher for information. Participants only considered distance learning when they are out of school due to expulsion (Runhare, 2010). The other issue with distance learning is that there is need to use computers and internet, and in Zimbabwe these are not easily accessible.

Another reason why students wanted to learn online is that they said they would benefit through interaction with other students from other countries. In addition, students also felt the need to develop their computer skills. This, in students' view, would increase their job prospects when computer skills are required. Students believed that their failure to use computers at their school was because of lack of computer skills, and the lack of interest and skill of their teachers. Another major handicap to use of computers was lack of electricity. Zimbabwe is grappling with electricity shortages, one of the major issues hindering economic development (Gonde \& Makonye, 2012). Some of the participants believed that the school did not have enough computers to accommodate all the students. The school in this study had 40 working computers for 700 students.

\section{Conclusions and Recommendations}

This study examined students' perceptions and the perceived advantages of online learning. Zimbabwe is a developing country and most people, especially students do not have access to the internet. Due to the economic situation in Zimbabwe, the Internet is used by the well-to-do, but it is not restricted from others when there are 
computers and electricity provided in the schools and public areas. Participating students expressed understanding of online education and showed enthusiasm to learn using computers. In this regard, based on the findings, it is recommended that government should make computers and suitable power available in poor rural communities.

Providing computers in schools alone may not be enough. There is also need to train teachers in using computers and the Internet to teach. The training should be aimed at equipping teachers with the skills to develop and teach online courses. Zimbabwe is well known for improving teacher skills through staff development programs (Tarusikirwa, 2004) and can implement these when training teachers how to teach using computers. The government may also introduce computer programs at colleges to train teachers in online teaching and learning techniques. Government may make these courses mandatory so that every newly trained teacher would be in a position to teach using computers.

Online learning needs to be taught by qualified trained personnel, who have the skills to deliver online lessons; hence teachers should be trained so that they can be effective in their teaching. For the students to be able to learn online, teachers need to be trained and have effectively online support systems. As a stop-gap measure, the government, through bilateral relations with other countries, may embark on a government to government initiative for computer teachers in other countries to help teach those teachers in Zimbabwe. Additionally, online mentoring can be established with sister-schools so that more experienced online educators can mentor and model the online teaching behaviors for less experienced teachers. Opportunities for Zimbabwe's students and teachers to observe online classes in other schools could be created, where teachers and learners are experienced and good at online learning.

Students identified the shortage of electricity as a hindrance to the full use of the computers available at their school. It is recommended that the government improve electricity supply through importation (Gonde \& Makonye, 2012) from regional countries. At a local level, schools may use generators, rechargeable batteries, or solar energy to generate electricity exclusively for computer power supply during power outages. Schools might appeal for funds from the donor community, or come up strategies to raise money for buying generators.

Invaluable resources offered by the Internet may prove beneficial to students. Government in general and schools in particular should not let this valuable form of education be missed by Zimbabwe. Students should be encouraged to use computers both at home and at school. This also calls for the government and responsible authorities to provide computers to schools in Zimbabwe. The use of computers in education is growing and Zimbabwean schools should not be left behind. Zimbabwe as a whole, should rise to the challenge and work towards competing with other countries in terms of providing a good education for its citizens embracing online learning.

The study was limited to two schools, and in future the study might be extended to include many schools including those in the urban areas. In addition, the study only focused on Advanced level students in a convenience sample who are expected to do research and gather important information on the Internet. It will be interesting to see if the same results will be realized if Ordinary level students and a sample of students suitable to develop generalizable results were to participate in the study.

\section{References}

Abarashi, M. (2011). Improving education through distance education and online learning. Nature and Science, $9(8), 55-58$.

Antunes, R. (2008). E/b-learning activities and high school pedagogy. Proceedings of World Academy of Science: Engineering \& Technology, 34, 748-751.

Barbour, K. M., \& Reeves, C. T. (2009). The reality of virtual schools: A review of the literature. Computers and Education, 52(2), 402-416. http://dx.doi.org/10.1016/j.compedu.2008.09.009

Bukaliya, R., \& Musika, F. (2011). Assessing the receptivity of open and distance learning programs among 
ordinary and advanced level students: A case of the Zimbabwe Open University. International Journal on New Trends in Education and Their Implications, 2(3), 73-87.

Calandro, E. Stork, C., \& Gillwald, A. (2012). Internet going mobile: Internet access and usage in 11 African countries. Retrieved from http://www.researchictafrica.net/publications/Country_Specific_Policy_Briefs/Internet_going_mobile__Internet_access_and_usage_in_11_African_countries.pdf

California Distance Learning Project. (2011). What is distance learning? Retrieved from http://www.cdlponline.org/index.cfm?fuseaction=whatis\&pg $=8$

Chimhenga, S., \& Musarurwa, C. (2012). Provision of open distance learning to students with hearing impairment in institutions of higher learning: The case of Zimbabwe Open University. International Journal of Social Sciences and Education, 2(1), 301-309.

Coleman, S. (2012). Why do students like online learning? Retrieved from http://www.worldwidelearn.com/education-articles/benefits-of-online-learning.htm

Creswell, J. W. (2007). Educational research: Planning, conducting, and evaluating quantitative and qualitative research. Boston, MA: Pearson Education.

Derbyshire, H. (2003). Gender issues in the use of computers in education in Africa. Retrieved from http://www.schoolnetafrica.org/fileadmin/resources/Gender\%20Report.pdf

Florida Center for Instructional Technology. (2009). A teacher's guide to distance learning. Retrieved from http://fcit.usf.edu/distance/chap1.htm

Gonde, P., \& Makonye, K. (2012). Zimbabwe faces blackout. Retrieved from http://www.madisonzim.com/What_s_New/Latest_News__Developments/Zim_faces_blackout.pdf

Hranstinski, S. (2008). Asynchronous and synchronous e-learning. Educause Quarterly, 4, 5-55.

International Association for K-12 Online Learning [iNACOL]. (2011). The online learning definitions project. Retrieved from http://www.inacol.org/research/docs/iNACOL_DefinitionsProject.pdf

Konyana, S., \& Konyana, E. G. (2013). Computerization of rural schools in Zimbabwe: Challenges and opportunities for sustainable development: The case of Chipinge district, south-east Zimbabwe. African Journal of Teacher Education, 3(2), 1-12. http://dx.doi.org/10.21083/ajote.v3i2.2156

Kurasha, P. (2003). Access to tertiary education as a national strategy for development: The Zimbabwe Open University Case. Retrieved from http://siteresources.worldbank.org/INTAFRREGTOPTEIA/Resources/primrose kurasha.pdf

Kurasha, P. (2007). The transformative aspect of open and distance learning towards equity and national brain gain: The Zimbabwe Open University case. Retrieve from http://www2.aau.org/corevip07/papers/sec-docs/Kurasha.pdf

Kurasha, P. (n. d.). Higher education and open and distance education as a strategy for national development: the ZOU case. Retrieved from

http://portal.unesco.org/pv_obj_cache/pv_obj_id_24F182CF637F1CFDAEAA8A561835455898CE000 0/filename/Kurasha.pdf

Lemley, D., Sudweeks, R., Howell, S., Laws, R., \& Sawyer, O. (2007). The effects of immediate and delayed feedback on secondary distance learners. Quarterly Review of Distance Education, 8(3), 251-260.

Loveland, T., Miyakawa, H., \& Yoshitaka, H. (2004). International collaboration in secondary level education. Journal of Technology Studies, 30(3), 10-19. http://dx.doi.org/10.21061/jots.v30i3.a.2

Mafa, O., Mpofu, J., \& Chimhenga, S. (2013). Combining face to face and open and distance learning at Zimbabwe Open University: Prospects, challenges and way forward. Online Journal of Education Research, 2(1), 11-17.

Metz, K. (2010). Benefits of online courses in career and technical education. Techniques: Connecting Education and Careers, 85(6), 20-23.

Milcheva, D. D. (2012). Basic characteristics in the structuring of industrial business and entrepreneurial training by parallel distance learning. Journal of the University of Chemical Technology \& Metallurgy, 47(3), 341-346.

Ministry of Education. (2004). National report of the development of education. Retrieved from 
Student perceptions of distance learning at advanced level in Zimbabwe

http://www.ibe.unesco.org/International/ICE47/English/Natreps/reports/zimbabwe.pdf

Nyaruwata, T. L. (2011). Open and distance learning: Strengthening the space of higher education, Zimbabwe's challenges and experiences. Retrieved from

http://events.aau.org/userfiles/file/corevip11/papers/leonarah_nyaruwata_Promoting_ODL.pdf

Picciano, G. A., Seaman, J., \& Day, S. (2011). Online learning Illinois high schools: Has the time come?

Retrieved from

http://www.babson.edu/Academics/Documents/babson-survey-research-group/online-learning-illinois-h igh.pdf

Roblyer, M. D. (1999). Is choice important in distance learning? A study of student motives for taking Internet-based courses at the high school and community college levels. Journal of Research on Computing in Education, 32(1), 157-171. http://dx.doi.org/10.1080/08886504.1999.10782621

Runhare, T. (2010). A comparative case study of institutional responsiveness to mainstreaming of pregnant learners in formal education. Retrieved from http://upetd.up.ac.za/thesis/available/etd-05132011-100147/unrestricted/00front.pdf

Siegle, D. (2010). The changing nature of universities: Going online. Gifted Child Today, 34(3), 56-61.

Subrahmanyan, K., Greenfield, P., Kraut, R., \& Gross, E. (2001). The impact of computer use on children's and adolescents' development. Applied Developmental Psychology, 22, 7-30. http://dx.doi.org/10.1016/S0193-3973(00)00063-0

Tarusikirwa, M. C. (2004). Technology for instruction in distance and open learning: Experiences from Matebeleland north region, Zimbabwe. Malaysian Online Journal of Instructional Technology, 1(1), $30-32$.

UNICEF. (2008). Education statistics: Zimbabwe. Division of policy and practice, statistics and monitoring section. Retrieved from http://www.childinfo.org/files/ESAR Zimbabwe.pdf

US Department of education. (2010). Evaluation of evidence-based practices in online learning: A meta-analysis and a review of online learning studies. Retrieved from http://www2.ed.gov/rschstat/eval/tech/evidence-based-practices/finalreport.pdf

Yang, M. (2008). Rethinking lifelong learning through online distance learning in Chinese educational policies, practices and research. British Journal of Educational Technology, 39(4), 583-597. http://dx.doi.org/10.1111/j.1467-8535.2007.00766.x

Zindi, F. (1997). Open and distance learning systems for people with disabilities. Journal of Social Development in Africa, 12(2), 91-97. 
Gomba, C. 